\title{
Koszty wymiaru i poboru podatku rolnego na przykładzie gmin wiejskich województwa opolskiego
}

\section{Wstęp}

Zagadnienia podatkowe analizowane są w kontekście formułowania modeli zachowania i wspólnych relacji między podatnikami i urzędami skarbowymi. Oddziaływanie tych podmiotów skutkuje zarówno zjawiskami nielegalnego unikania opodatkowania, jak i kształtowania administracyjnych kosztów funkcjonowania aparatu skarbowego [Gill 2003].

System podatkowy jest zbiorem podatków istniejących w określonym czasie w danym państwie, podporządkowanych wspólnej idei i tworzących wewnętrznie porządkowaną logiczną i jednolitą całość. Zatem system podatkowy to całokształt prawno-organizacyjnych form opodatkowania, tj. poszczególne podatki oraz elementy konstrukcji podatków (ulgi, zwolnienia, itp.) [Tegler 1992].

W literaturze sformułowano założenia o charakterze teoretycznym, dotyczące kształtowania systemu podatkowego intensyfikującego realizację zakładanych i stawianych przed nim celów. Sformułowano m.in. cztery uniwersalne zasady racjonalizacji systemu podatkowego określane jako baza dla poszukiwania i konstruowania racjonalnego systemu podatkowego [Grądalski 2004]:

- konieczności postrzegania systemu podatkowego w szerszym kontekście strategicznych celów rozwojowych państwa,

- ekwiwalentnej wymiany między państwem a podatnikiem,

- neutralności systemu podatkowego względem mechanizmu rynkowego,

- minimalizacji kosztów procesu fiskalnego.

Przesłanki doskonalenia systemów podatkowych są analizowane w kontekście zwiększania ich efektywności. Sprawność systemu podatkowego jest określana na podstawie stopnia fiskalizmu, czyli polityki państwa zmierzającej do 


\section{8}

zwiększania wpływów budżetowych tytułem podatków. Powszechnie obowiązujące $\mathrm{w}$ literaturze przedmiotu jest twierdzenie o stopniu fiskalizmu na poziomie około 10\% [Grądalski 2006, Gruziel 2012]. W Polsce skala fiskalizmu jest wyrażana relacją dochodów publicznych do PKB, która w ostatnich latach kształtuje się na poziomie około $30-40 \%$. Maksymalizowanie obciążeń podatkowych będących głównym źródłem finansowania wydatków państwa oraz maksymalizowania dochodów powoduje dodatkowe straty w dobrobycie. Zwiększając główne źródło finansowania wydatków, powodujemy rozszerzenie sfery publicznej, wzrost fiskalizmu, a efektem tych działań jest ograniczenie sprawności działania sektora publicznego [Dziemianowicz 2009].

\section{Cel metodyka badań}

Celem opracowania jest próba określenia kosztów wymiaru i poboru podatku rolnego na przykładzie gmin wiejskich położonych na terenie województwa opolskiego. Nieujawnianie właściwego nazewnictwa gmin było warunkiem udostępnienia informacji liczbowych. Podstawę przeprowadzonych badań stanowiły dane liczbowe pochodzące $\mathrm{z}$ budżetów gmin wiejskich. Okres badawczy obejmuje lata 2004-2009. Dobór gmin był celowy, a kryterium stanowił charakter gminy. Przedmiotem analizy były gminy wiejskie położone na terenie województwa opolskiego, w których udział użytków rolnych stanowił około $70 \%$ powierzchni. Dane liczbowe wykorzystano do określenia poszczególnych kategorii kosztów ponoszonych $\mathrm{w}$ procesie pozyskiwania podatku rolnego. Schemat określenia kosztów wymiaru podatku opiera się na założeniu, że wydatki nie są zestawione z użytecznością dóbr publicznych i efektami redystrybucji dochodów. Szacunek kosztów procesu fiskalnego sprowadza się do kwantyfikacji obciążeń generowanych przez gminę.

W przyjętym modelu podjęto próbę określenia kosztów procesu fiskalnego podatku rolnego (koszty wymiaru i poboru podatku rolnego). Szacunek kosztów pozyskiwania podatku rolnego przeprowadzono według schematu: koszty procesu fiskalnego stanowią sumę kosztów wymiaru i poboru podatku oraz koszty procesu legislacyjnego. Inspirując się rozwiązaniami Grądalskiego [2006], przyjęto następujące założenia:

1. Koszty osobowe stanowią wynagrodzenia pracowników na etacie oraz osób spoza urzędu gminy zaangażowanych w wymiar i pobór podatku rolnego.

2. Koszty rzeczowe wymiaru podatku rolnego, w skład których wchodzą m.in. zakup artykułów biurowych, przesyłki pocztowe, dodatkowe rodzaje kosztów rzeczowych. 
3. Koszty inne obejmują kategorie wydatków wpływających na wymiar i pobory podatku rolnego, np. koszty z tytułu prowizji bankowych od wpłat na konto, wydatki na ZUS (Zakład Ubezpieczeń Społecznych), Fundusz Pracy, odpisy na zakładowy fundusz świadczeń socjalnych, prowizje od wpłat do banków.

4. Koszty całkowite stanowią sumę kosztów aparatu skarbowego (administracji podatkowej na szczeblu gminy).

5. Koszty utrzymania aparatu skarbowego stanowią zwiększenie kosztów aparatu skarbowego o wydatki o charakterze majątkowym, czyli inwestycje w aparat skarbowy ( $10 \%$ całkowitych kosztów funkcjonowania aparatu skarbowego).

6. Koszt wymiaru podatku, czyli koszt procesu legislacyjnego określono na poziomie $10 \%$ całkowitych kosztów związanych z funkcjonowaniem administracji podatkowej na szczeblu gminy.

W celu relatywizacji kosztów opodatkowania zakłada się zestawienie kosztów wymiaru podatku rolnego $\mathrm{z}$ dochodami budżetu gminy uzyskanymi tytułem tego obciążenia.

\section{Wyniki badań}

W tabeli 1 przedstawiono kategorie pozwalające na oszacowanie kosztów wymiaru i pozyskiwania podatku rolnego w gminie wiejskiej współtworzonej przez 13 sołectw. W proces pozyskiwania podatku rolnego było zaangażowanych 13 osób spoza gminy i jeden pracownik urzędu gminy. Roczny koszt utrzymania pracowników zatrudnionych na etacie kształtował się w granicach od $8640 \mathrm{zl}$ w 2004 roku do 13824 zł w 2008 roku (tab. 1). Tylko w 2009 roku w relacji do roku poprzedniego wystąpiło zmniejszenie wynagrodzeń pracowników gminy o $20,4 \%$. W pozostałych latach wynagrodzenia $\mathrm{z}$ tytułu pozyskiwania podatku rolnego wykazywały wzrost $\mathrm{w}$ stosunku do roku poprzedniego na poziomie od $2,9 \%$ w 2007 roku do $34,8 \%$ w 2008 roku. Wynagrodzenia pracownika gminy z tytułu uczestniczenia $\mathrm{w}$ procesie wymiaru i poboru podatku rolnego w skali miesiąca kształtowały się od 720 zł w 2004 roku do 1152 zł w 2008 roku.

Wynagrodzenia łącznie wypłacane osobom zaangażowanym $\mathrm{w}$ proces wymiaru i poboru podatku rolnego stwierdzono w kwotach od 12 940,7 zł w 2004 roku do 21442,4 zł w 2008 roku. Największy wzrost wynagrodzeń (o 41,2\%) stwierdzono w 2008 roku. Tylko w 2006 roku odnotowano spadek wynagrodzeń w stosunku do roku poprzedniego o 3,5\%. Wynagrodzenia pracowników spoza gminy kształtowały się od 3771,6 zł w 2006 roku do 7618,4 zł 
Tabela 1

Zestawienie kosztów procesu fiskalnego gminy wiejskiej nr 1 położonej w województwie opolskim w latach 2004-2009

\begin{tabular}{|c|c|c|c|c|c|c|}
\hline \multirow{2}{*}{ Pozycje kosztów } & \multicolumn{6}{|c|}{ Lata } \\
\hline & 2004 & 2005 & 2006 & 2007 & 2008 & 2009 \\
\hline 1. Liczba etatów w gminie & 1 & 1 & 1 & 1 & 1 & 1 \\
\hline $\begin{array}{l}\text { 2. Liczba etatów spoza } \\
\text { gminy }\end{array}$ & 13 & 13 & 13 & 13 & 13 & 13 \\
\hline $\begin{array}{l}\text { 3. Roczny koszt wynagro- } \\
\text { dzeń pracowników na } \\
\text { etacie [zł] }\end{array}$ & 8640,0 & 9154,0 & 9964,8 & 10252,8 & 13824,0 & 11001,2 \\
\hline $\begin{array}{l}\text { 4. Roczny koszt wynagro- } \\
\text { dzeń pracowników spo- } \\
\text { za gminy (sołtysi) [zł] }\end{array}$ & 4300,7 & 4633,5 & 3771,6 & 4938,4 & 7618,4 & 7550,4 \\
\hline 5. Koszty rzeczowe [zł] & 725,3 & 1000,0 & 26677,8 & 1193,9 & 644,6 & 104,9 \\
\hline $\begin{array}{l}\text { 6. Koszty inne zwiazane } \\
\text { z poborem podatku } \\
\text { rolnego [zł] }\end{array}$ & 13215,7 & 6800,0 & 1746,6 & 6506,8 & 1752,7 & 3815,5 \\
\hline $\begin{array}{l}\text { 7. Koszty aparatu skarbo- } \\
\text { wego }(3+4+5+6) \text { [zł] }\end{array}$ & 26881,7 & 21587,5 & 42160,8 & 22891,9 & 23839,7 & 22472,0 \\
\hline 8. Inwestycje $(7 \times 0,1)[z ł]$ & 2688,2 & 2158,8 & 4216,1 & 2289,2 & 2384,0 & 2247,2 \\
\hline $\begin{array}{l}\text { 9. Utrzymanie aparatu } \\
\text { skarbowego }(7+8)[z ł]\end{array}$ & 29569,8 & 23746,3 & 46376,8 & 25181,1 & 26223,6 & 24719,2 \\
\hline $\begin{array}{l}\text { 10. Koszt procesu legisla- } \\
\text { cyjnego }(9 \times 0,1)[\mathrm{z}\}]\end{array}$ & 2957,0 & 2374,6 & 4637,7 & 2518,1 & 2622,4 & 2471,9 \\
\hline $\begin{array}{l}\text { 11. Koszt poboru podatku } \\
(9+10)[z ł]\end{array}$ & 32526,8 & 26120,9 & 51014,5 & 27699,2 & 28846,0 & 27191,1 \\
\hline $\begin{array}{l}\text { 12. Wpływy z tytułu podatku } \\
\text { rolnego [zł] }\end{array}$ & 632527,0 & 567453,1 & 687257,3 & 678203,4 & 1023810,6 & 928854,1 \\
\hline $\begin{array}{l}\text { 13. Podatek rolny/koszty } \\
\text { wymiaru podatku } \times \\
\times 100[\%]\end{array}$ & 1944,6 & 2172,4 & 1347,2 & 2448,5 & 3549,2 & 3416,0 \\
\hline $\begin{array}{l}\text { 14. Koszty wymiaru i poboru } \\
\text { podatku/podatek rolny } \times \\
\times 100[\%]\end{array}$ & 5,1 & 4,6 & 7,4 & 4,1 & 2,8 & 2,9 \\
\hline $\begin{array}{l}\text { 15. Koszty wymiaru i poboru } \\
\text { podatku/liczba zatrud- } \\
\text { nionych łącznie [zł] }\end{array}$ & 2323,3 & 1865,8 & 3643,9 & 1978,5 & 2060,4 & 1942,2 \\
\hline $\begin{array}{l}\text { 16. Wpływy z tytułu podatku } \\
\text { rolnego/liczba zatrud- } \\
\text { nionych łącznie [zł] }\end{array}$ & 45180,5 & 40532,4 & 49089,8 & 48443,1 & 73129,3 & 66346,7 \\
\hline $\begin{array}{l}\text { 17. Koszt wynagrodzeń } \\
\text { łącznie/wpływy z podat- } \\
\text { ku rolnego [\%] }\end{array}$ & 2,0 & 2,4 & 2,0 & 2,2 & 2,1 & 2,0 \\
\hline
\end{tabular}

Źródło: Opracowanie własne na podstawie informacji z gminy nr 1. 
w 2008 roku. Zmiany wynagrodzeń w relacji do roku poprzedniego kształtowały się od $-18,6 \%$ w 2005 roku do $154,3 \%$ w 2008 roku. Wynagrodzenia dla pracownika spoza gminy tytułem uczestniczenia w pozyskiwaniu podatku rolnego w przeliczeniu na kwartał kształtowało się od 45,3 zł w 2006 roku do 91,6 zł w 2008 roku (tab. 1).

Koszty rzeczowe realizowane $\mathrm{w}$ gminie $\mathrm{nr} 1$ charakteryzowało duże zróżnicowanie - od 644,6 zł w 2008 roku do 26 677,8 zł w 2006 roku. Dynamikę tej kategorii kosztów można powiązać z dostępem do środków unijnych przeznaczanych na poprawę zaplecza administracyjnego gminy.

Inne koszty związane $\mathrm{z}$ poborem podatku rolnego wynosiły od $1746,6 \mathrm{zl}$ w 2006 roku do 13215,7 zł w 2004 roku. W latach 2004-2009 zmiany kosztów okołopłacowych w stosunku do roku poprzedniego kształtowały się od 25,7\% w 2006 roku do 372,5\% w 2007 roku. W latach 2004-2009 2-krotnie zwiększono poziom kosztów innych w relacji do roku poprzedniego - o 4760,2 zł $(372,5 \%)$ w 2007 roku i o $2062,8 \mathrm{zł}(217,7 \%)$ w 2009 roku. W pozostałych latach wydatki o charakterze okołopłacowym zmniejszyły się w stosunku do roku poprzedniego odpowiednio o 48,5\% w 2005 roku, o 74,3\% w 2006 roku oraz o $70,4 \%$ w 2008 roku.

Największy poziom kosztów poniesionych na funkcjonowanie administracji podatkowej (w kwocie 42 160,8 zł) odnotowano w 2006 roku. W pozostałych latach koszty aparatu skarbowego wahały się w granicach od $21587,5 \mathrm{zl}$ w 2005 roku do 26881,7 zł w 2004 roku. W grupie kosztów aparatu skarbowego wydatki na wynagrodzenia łącznie stanowiły udział od 29,6\% w 2006 roku do $75 \%$ w 2009 roku. Znaczny udział w kosztach aparatu skarbowego - w wysokości 49,2\% w 2004 roku stanowily koszty inne, a w 2006 roku 63,3\% kosztów administracji podatkowej stanowiły koszt rzeczowe.

Koszty poboru podatku rolnego odnotowano na poziomie od $26120,9 \mathrm{zl}$ w 2005 roku do 51014,5 zł w 2006 roku. Zmiany tej kategorii wydatków w stosunku do roku poprzedniego w latach 2006 i 2008 zwiększyły się odpowiednio o 195,3 i 104,1\%. W pozostałych latach koszty poboru podatku rolnego zmniejszyły się w relacji do roku poprzedniego (tab. 1).

Wpływy z tytułu podatku rolnego $\mathrm{w}$ gminie $\mathrm{nr} 1$ kształtowały się na poziomie od 567 453,1 zł w 2005 roku do 1023 810,6 zł w 2008 roku. W latach 2006 i 2008 zwiększyły się w relacji do roku poprzedniego odpowiednio o $21,1 \mathrm{oraz}$ $51 \%$. W pozostałych latach zmniejszenie wpływów z tytułu podatku rolnego wykazały wielkości około 10\%, co można tłumaczyć zwiększeniem skali korzystania z ulg i zwolnień podatkowych.

$\mathrm{W}$ gminie nr 1 stwierdzono znaczną przewagę wpływów z tytułu podatku rolnego nad szacowanymi wydatkami poniesionymi na pozyskanie tego obciążenia. Największą, około 35-krotną dominację wpływów z tytułu podatku rol- 
nego nad kosztami pozyskania, odnotowano w latach 2008-2009. W pozostałych latach rozbieżność kształtowała się od 1347,2\% w 2006 roku do 2448,5\% w 2007 roku. Wielkości tej relacji świadczą o wysokiej efektywności poboru podatku rolnego. Tezę tę potwierdza wskaźnik będący relacją kosztów pozyskania podatku rolnego do wpływów z tego tytułu. Koszt pozyskania 1 zł podatku rolnego kształtował się na poziomie od niespełna 3 groszy w latach 2008-2009 do 7 groszy w 2006 roku. Relacja wskaźnika potwierdza niskie koszty procesu fiskalnego podatku rolnego.

Koszty ponoszone na pozyskiwanie podatku rolnego w relacji do liczby zatrudnionych w latach 2004-2009 były niższe niż kwoty wynagrodzeń z tytułu procesu fiskalnego. Wpływy z podatku rolnego w przeliczeniu na osobę zaangażowaną $\mathrm{w}$ proces wymiaru i poboru podatku kształtowały się pomiędzy 40 532,4 zł w 2005 roku a 73129,3 zł w 2008 roku. Wskaźnik, będący relacją wynagrodzeń łącznie do wpływów tytułem podatku rolnego, potwierdził niskie koszty procesu fiskalnego. Wynagrodzenia łącznie stanowiły $2 \%$ przychodów uzyskanych tytułem podatku rolnego (tab. 1).

W tabeli 2 przedstawiono kategorie pozwalające na określenie kosztów procesu fiskalnego w gminie wiejskiej nr 2 położonej w województwie opolskim. $\mathrm{W}$ proces pozyskiwania podatku rolnego zaangażowanych był 1 urzędnik gminy zatrudniony na etacie oraz 9 osób spoza urzędu gminy (tab. 2). Wynagrodzenia dla pracowników gminy z tytułu wymiaru i poboru podatku rolnego kształtowały się od 14382 zł w 2004 roku do 21784 zł w 2009 roku. W badanym okresie tylko w 2008 roku odnotowano zmniejszenie wynagrodzeń w porównaniu z rokiem poprzednim o kwotę $1306 \mathrm{zł}(6,7 \%)$. W pozostałych latach stwierdzono zwiększenie wynagrodzeń $\mathrm{w}$ relacji do roku poprzedniego o kwoty od $184 \mathrm{zł}(1,2 \%)$ w 2006 roku do 3764 zł $(24,1 \%)$ w 2007 roku.

Roczny koszt wynagrodzeń z tytułu pozyskiwania podatku rolnego przez pracowników spoza gminy kształtował się od 1694,8 zł w 2006 roku do 5696,8 zł w 2009 roku. Wynagrodzenia dla sołtysów w relacji do roku poprzedniego zmniejszyło się dwukrotnie - w 2005 roku o 130 zł (4,2\%) oraz w 2006 roku o $1261,6 \mathrm{zł}(42,7 \%)$. W pozostałych latach zwiększano koszty utrzymania pracowników spoza gminy w relacji do roku poprzedniego. Zróżnicowanie wynagrodzeń dla pracowników spoza gminy było wynikiem przyjętych rozwiązań w ramach projektowania budżetu gminy (tab. 2).

Wydatki rzeczowe w gminie nr 2 kształtowały się od 11962 zł w 2004 roku do $16860 \mathrm{zł} \mathrm{w} 2005$ roku. Koszty rzeczowe dwukrotnie zmniejszono w stosunku do roku poprzedniego o kwoty 4238 zł $(25,1 \%)$ w 2006 roku oraz o 3449 zł $(22,1 \%)$ w 2008 roku. W pozostałych latach wzrost kosztów rzeczowych w relacji do roku poprzedniego stwierdzono na poziomie od $2965 \mathrm{zl}(23,5 \%) \mathrm{w} 2006$ roku do 4898 zł $(40,9 \%)$ w 2005 roku. Można wnioskować o względnie regularnej 
skali dokonywanych inwestycji w urzędzie gminy. Koszty inne w gminie $\mathrm{nr} 2$ odnotowano w wysokości od 55633 zł w 2004 roku do 83852 zł w 2009 roku. Dwukrotnie odnotowano zmniejszenie kosztów okołopłacowych w relacji do roku poprzedniego o kwoty 6932 zł w 2006 roku oraz o 6168 zł w 2008 roku (tab. 2).

\section{Tabela 2}

Zestawienie kosztów procesu fiskalnego gminy wiejskiej nr 2 położonej w województwie opolskim w latach 2004-2009

\begin{tabular}{|c|c|c|c|c|c|c|}
\hline \multirow{2}{*}{ Pozycje kosztów } & \multicolumn{6}{|c|}{ Lata } \\
\hline & 2004 & 2005 & 2006 & 2007 & 2008 & 2009 \\
\hline 1. Liczba etatów w gminie & 1 & 1 & 1 & 1 & 1 & 1 \\
\hline 2. Liczba etatów spoza gminy & 9 & 9 & 9 & 9 & 9 & 9 \\
\hline $\begin{array}{l}\text { 3. Roczny koszt wynagro- } \\
\text { dzeń pracowników na } \\
\text { etacie }[z ł]\end{array}$ & 14382,0 & 15464,0 & 15648,0 & 19412,0 & 18106,0 & 21784,0 \\
\hline $\begin{array}{l}\text { 4. Roczny koszt wynagro- } \\
\text { dzeń pracowników spoza } \\
\text { gminy (sołtysi) [zł] }\end{array}$ & 3086,4 & 2956,4 & 1694,8 & 4020,0 & 4238,4 & 5696,8 \\
\hline 5. Koszty rzeczowe [zł] & 11962,0 & 16860,0 & 12622,0 & 15587,0 & 12138,0 & 15150,0 \\
\hline $\begin{array}{l}\text { 6. Koszty inne zwiazane } \\
\text { z poborem podatku } \\
\text { rolnego [zł] }\end{array}$ & 55633,0 & 62911,0 & 55979,0 & 74167,0 & 67999,0 & 83852,0 \\
\hline $\begin{array}{l}\text { 7. Koszty aparatu skarbowe- } \\
\text { go }(3+4+5+6)[\mathrm{z}\rfloor\end{array}$ & 85063,4 & 98191,4 & 85943,8 & 113186,0 & 102481,4 & 126482,8 \\
\hline 8. Inwestycje $(7 \times 0,1)[\mathrm{zł}]$ & 8506,3 & 9819,1 & 8594,4 & 11318,6 & 10248,1 & 12648,3 \\
\hline $\begin{array}{l}\text { 9. Utrzymanie aparatu skar- } \\
\text { bowego }(7 \times 8)[\mathrm{zł}]\end{array}$ & 93569,7 & 108010,5 & 94538,2 & 124504,6 & 112729,5 & 139131,1 \\
\hline $\begin{array}{l}\text { 10. Koszt procesu legislacyj- } \\
\text { nego }(9 \times 0,1)[z ł]\end{array}$ & 9357,0 & 10801,1 & 9453,8 & 12450,5 & 11273,0 & 13913,1 \\
\hline $\begin{array}{l}\text { 11. Koszt poboru podatku } \\
(9+10)[\mathrm{z}\}]\end{array}$ & 102926,7 & 118811,6 & 103992,0 & 136955,1 & 124002,5 & 153044,2 \\
\hline $\begin{array}{l}\text { 12. Wpływy z tytułu podatku } \\
\text { rolnego [zł] }\end{array}$ & 158890,5 & 173602,2 & 140971,1 & 168783,0 & 226915,3 & 225970,1 \\
\hline $\begin{array}{l}\text { 13. Podatek rolny/koszty wy- } \\
\text { miaru podatku } \times 100[\%]\end{array}$ & 154,4 & 146,1 & 135,6 & 123,2 & 183,0 & 147,7 \\
\hline $\begin{array}{l}\text { 14. Koszty wymiaru i poboru } \\
\text { podatku/podatek rolny } \times \\
\times 100[\%]\end{array}$ & 64,8 & 68,4 & 73,8 & 91,1 & 54,6 & 67,7 \\
\hline $\begin{array}{l}\text { 15. Koszty wymiaru i poboru } \\
\text { podatku/liczba zatrudnio- } \\
\text { nych łącznie [zł] }\end{array}$ & 10292,7 & 11881,2 & 10399,2 & 13695,5 & 12400,2 & 15304,4 \\
\hline $\begin{array}{l}\text { 16. Wpływy z tytułu podatku } \\
\text { rolnego/liczba zatrudnio- } \\
\text { nych łącznie [zł] }\end{array}$ & 15889,1 & 17360,2 & 14097,1 & 16878,3 & 22691,5 & 22597,0 \\
\hline $\begin{array}{l}\text { 17. Koszt wynagrodzeń łącz- } \\
\text { nie/wpływy z podatku } \\
\text { rolnego [\%] }\end{array}$ & 11,0 & 10,6 & 12,3 & 13,9 & 9,8 & 12,2 \\
\hline
\end{tabular}

Źródło: Opracowanie własne na podstawie informacji z gminy nr 2. 


\section{4}

Koszty administracji podatkowej na szczeblu gminy kształtowały się na poziomie od 85 063,4 zł w 2004 roku do 1 264,826 zł w 2009 roku. Zwiększenie kosztów aparatu skarbowego w relacji do roku poprzedniego stwierdzono trzykrotnie w 2005 roku o 15,4\%, o 31,7\% w 2007 roku oraz 23,4\% w 2009 roku. $\mathrm{W}$ pozostałych latach ograniczono skalę wydatków w odniesieniu do roku poprzedniego o 15\% w 2004 roku oraz 31,7\% w 2007 roku.

Koszty fiskalne poboru podatku rolnego w gminie nr 2 kształtowały się od 102926,7 zł w 2004 roku do 153 044,2 zł w 2009 roku. W latach 2004-2009 dwukrotnie odnotowano zmniejszanie tej kategorii kosztów w relacji do roku poprzedniego o kwoty $14819,6 \mathrm{zł} \mathrm{w} 2006$ roku (12,5\%) oraz 12 952,6 zł w 2008 roku, co stanowiło $9,5 \%$. W pozostałych latach odnotowano coroczne zwiększanie kosztów pozyskiwania podatku w relacji do roku poprzedniego.

Wpływy z tytułu podatku rolnego $\mathrm{w}$ gminie nr 2 kształtowały się od 140971,1 zł w 2006 roku do 226 915,3 zł w 2008 roku. W 2006 roku odnotowano zmniejszenie dochodów podatkowych z tytułu podatku rolnego względem roku poprzedniego o $19,8 \%$, co wskazuje na zwiększenie skali ulg i zwolnień podatkowych. Relacja kwot podatku rolnego i kosztów poboru kształtowała się na poziomie od 123,2\% w 2007 roku do $183 \%$ w 2008 roku. Koszty poniesione na pozyskiwanie podatku rolnego były mniejsze niż wpływy uzyskane z tytułu tego obciążenia. Relacja wpływów z tytułu podatku rolnego do kosztów wymiaru i poboru wskazuje, że pozyskanie $1 \mathrm{zł}$ dochodu z podatku rolnego wymaga poniesienia wydatków od $0,64 \mathrm{zł}$ w 2004 roku do 0,81 zł w 2007 roku.

Koszty pozyskiwania podatku rolnego na osobę zaangażowaną w proces fiskalny kształtowały się od 10 292,7 zł w 2004 roku do 15 304,4 zł w 2009 roku. Wpływy z tytułu podatku rolnego na osobę zatrudnioną stwierdzono w wysokości od 14097,1 zł w 2006 roku do 22 691,5 zł w 2008 roku. Koszty procesu fiskalnego $\mathrm{w}$ relacji do wynagrodzeń łącznie stwierdzono na poziomie od $9,8 \%$ w 2008 roku do $13,9 \%$ w 2007 roku.

Reasumując, na podstawie opracowanych wskaźników można stwierdzić, że koszt procesu fiskalnego $\mathrm{w}$ gminie $\mathrm{nr} 2$ był wyższy niż $\mathrm{w}$ gminie $\mathrm{nr} 1$ na poziomie od 203,8 do $562,8 \%$. Większe dochody tytułem z podatku rolnego stwierdzono $\mathrm{w}$ gminie $\mathrm{nr} 1$ na poziomie od 326,9 do 487,5\%. Łączne wynagrodzenia dla osób zaangażowanych w proces fiskalny podatku rolnego w przeliczeniu na osobę w gminie nr 2 były wyższe niż w gminie $\mathrm{nr} 1 \mathrm{o}$ wielkości od 187 do około $215,9 \%$. Na podstawie dokonanej analizy można wnioskować o wyższych kosztach procesu fiskalnego $\mathrm{w}$ gminie $\mathrm{nr} 2$. Pozyskanie $1 \mathrm{zł}$ dochodu tytułem podatku rolnego w gminie nr 1 wymagało wydatkowania od 0,04 do $0,07 \mathrm{zl}$, a w gminie nr 2 koszt oszacowano na poziomie od 0,54 do $0,81 \mathrm{zł}$. 


\section{Wnioski}

Na podstawie przeprowadzonych badań sformułowano następujące wnioski:

1. W przyjętej metodologii, zgodnie z założeniami teorii opodatkowania, podjęto próbę określenia kosztów wymiaru i poboru podatku rolnego, czyli skutków opodatkowania na poziomie budżetów gmin wiejskich. Stwierdzono znaczące zróżnicowanie kosztów procesu fiskalnego podatku rolnego w analizowanych gminach wiejskich województwa opolskiego.

2. Wynagrodzenia łącznie tytułem uczestniczenia w procesie wymiaru i poboru podatku rolnego były wyższe w gminie nr 2 o wielkości od 4 do $48 \%$. Wynagrodzenia $\mathrm{w}$ przeliczeniu na osobę zaangażowaną $\mathrm{w}$ pozyskiwanie tego obciążenia były około dwukrotnie większe $\mathrm{w}$ gminie $\mathrm{nr} 2$. Wynagrodzenia tytułem uczestniczenia w procesie fiskalnym można uznać jako czynnik zmniejszający efektywność procesu fiskalnego.

3. W gminie nr 1 stwierdzono około trzy- - czterokrotnie wyższe dochody tytułem podatku rolnego. Wpływy z tego obciążenia w przeliczeniu na osobę zaangażowaną $\mathrm{w}$ proces fiskalny były około dwukrotnie większe również w gminie $\mathrm{nr} 1$.

4. Pozyskanie 1 zł podatku rolnego w gminie nr 1 wymagało wydatków na poziomie 3-7 groszy. W gminie $\mathrm{nr} 2$ pozyskanie 1 zł podatku rolnego było skutkiem wydatkowania 50-80 groszy. Jako czynniki zwiększające efektywność procesu fiskalnego można uznać relatywnie niskie wynagrodzenia i koszty około płacowe oraz niską skalę ulg i zwolnień podatkowych.

\section{Literatura}

DZIEMIANOWICZ R., 2009: Nadmierny fiskalizm: Bariera czy stymulator funkcjonowania sektora publicznego?, Wydawnictwo Uniwersytetu w Białymstoku. Optimum - Studia Ekonomiczne 4(40), s. 138.

GILL J.: The nuts and bolts of revenue administration reform, Strona Banku Światowego: www1.worldbank.org/publicsector/tax/NutsBolts.pdf. 2003, s. 1-2.

GRĄDALSKI F., 2006: System podatkowy $w$ świetle teorii optymalnego opodatkowania, Szkoła Główna Handlowa, s. 90-95.

GRĄDALSKI F., 2004: Wstęp do teorii opodatkowania, Szkoła Główna Handlowa, Warszawa, s. 101-103, 161-167.

GRUZIEL K., 2012: Koszty procesu fiskalnego podatku rolnego na przykładzie gmin wiejskich z województwa małopolskiego, Zeszyty Naukowe SGGW w Warszawie Ekonomika i Organizacja Gospodarki Żywnościowej 99, s. 419. 
TEGLER E., 1992: Funkcje systemu podatkowego i ocena jego poprawności, [w:] System podatkowy. Zagadnienia teoretyczno-prawne, Wydawnictwo UŁ, Acta Universitatis Lodziensis, Folia Iuridica, s. 102.

\begin{abstract}
Abstrakt
W opracowaniu przedstawiono wyniki badań dotyczących kosztów procesu fiskalnego podatku rolnego na przykładzie gmin wiejskich położonych w województwie opolskim. Do określenia kosztów procesu fiskalnego wykorzystano kategorie kosztów wymiaru i poboru podatku rolnego oraz ich relacje do wpływów $\mathrm{z}$ tytułu podatku rolnego.

W gminie nr 1 stwierdzono około 3-krotnie wyższe dochody z tytułu podatku rolnego niż w gminie $\mathrm{nr} 2$. Wynagrodzenia tytułem uczestniczenia $\mathrm{w}$ procesie fiskalnym w gminie nr 1 było niższe o od 4 do $35 \%$ niż w gminie $\mathrm{nr} 2$.

Pozyskanie $1 \mathrm{zl}$ podatku rolnego $\mathrm{w}$ gminie $\mathrm{nr} 1$ wymagało wydatków na poziomie 3-7 groszy, a w gminie nr 2 około 50-80 groszy. Czynnikami kształtującymi efektywność procesu fiskalnego można uznać wynagrodzenia i koszty około płacowe tytułem uczestniczenia w procesie wymiaru i poboru podatku rolnego, wielkość dochodów tytułem podatku rolnego oraz korzystanie z ulg i zwolnień.
\end{abstract}

Słowa kluczowe: podatek rolny, wymiar podatku, fiskalizm

\title{
The costs of agricultural tax assessment and collection on the example of rural communes (NUTS 5) of Opolskie region (NUTS 2)
}

\begin{abstract}
The paper presents research concerning costs of agricultural tax assessment and collection on the example of rural communes (NUTS 5) of Opolskie region (NUTS 2). The costs of the fiscal process were based on the costs of tax assessment and tax collection, as well as their relations to incomes from agricultural tax. In commune No 1 . incomes from agricultural tax were approximately 3 times higher than in commune No 2. At the same time revenues for participating in the fiscal process in commune No 1 . were lower by $4 \%$ to $35 \%$ in comparison to commune No 2. Obtaining 1 PLN of agricultural tax in commune No 1. cost
\end{abstract}


about 0.03-0.07PLN, while in Commune No 2. it was as high as 0.5-0.8 PLN. The effectiveness of the fiscal process depended on the remunerations and other costs of tax assessment and collection, as well as on the level of incomes from agricultural tax and tax exemptions.

Key words: agricultural tax, tax assessment, fiscalism 
